\title{
LIGHT-INDUCED PHOTOACTIVATION OF HYPERICIN INHIBITS CELLULAR GROWTH IN PITUITARY ADENOMA CELL LINE AtT20/D16v-F2 (HYPERICIN INHIBITS CELLULAR GROWTH OF AtT20/D16v-F2)
}

\author{
Martina Mareková ${ }^{1}$, Jiřina Vávrová ${ }^{2}$, Doris Vokurková ${ }^{3}$, Jaroslav Cerman ${ }^{1}$
}

Charles University in Prague, Faculty of Medicine in Hradec Králové: Department of Medical Biochemistry ${ }^{1}$; Purkyně Military Medical Academy in Hradec Králové: Department of Radiobiology and Immunology2; University Teaching Hospital, Hradec Králové: Department of Clinical Immunology and Allergology ${ }^{3}$

Summary: Cultivation with 4-8 $\mu \mathrm{mol} / 1$ hypericin (specific proteinkinase C inhibitor) activated by light induced high inhibition of the rate of HL-60 cell growth. When hypericin treated cells were not exposed to light growth inhibition was insignificant. Cultivation with light activated hypericin in concentration $16 \mu \mathrm{mol} / 1$ slightly inhibited growth rate of AtT20/D16v-F2 cells. AtT20/D16v-F2 cells did not proliferate in presence of light activated $32 \mu$ mol/1 hypericin. Evidence of apoptosis was found in HL-60 cells treated with 1-8 $\mu \mathrm{mol} / 1$ light activated hypericin, with maximum of apoptotic cells detected after $8 \mu \mathrm{mol} / 1$ light activated hypericin. Light activated hypericin induces both apoptosis and necrosis in dose and time dependent manners in HL-60 cells, but causes only necrosis in AtT20/D16v-F2 cells.

Key words: AtT20/D16v-F2; Hypericin; Apoptosis; Proteinkinase C

\section{Introduction}

Hypericin is a natural pigment, isolated from Hypericum, a genus of plants widely distributed throughout the planet. Hypericin constitutes up to $0,05 \%$ of the plant substances. St. John's Wort, Hypericum perforatum is probably the richest source of hypericin (4). Chemically it is hydroxylated polycyclic quinon (7,14-dione-1,3,4,6,8,13-hexahydroxy-10,11-dimethyl-phenanthrol(1,10,9,8-opgra)perylene). Naturally occurring hypericin is often accompanied by pseudohypericin. During the last years some interesting properties of this compounds has been uncovered, which bring them into the consideration as a potential therapeutics in treatment of some types of tumour and viral diseases.

Virucidal activities of hypericin are intensively studied since 1988 (13). Mechanisms of antiviral action of hypericin are not sufficiently clarified yet. Hypericin effectively inactivates enveloped viruses, but is inactive against nonenveloped viruses $(8,16)$. This ability is enhanced by exposition to the light $(1,8,9)$. So far hypericin has been intensively studied mainly for its antiretroviral activity $(10,20)$.

Some studies show that growth and death of tumour cells differs then these of normal cells. Whether the anticancer agents (ionising radiation and cytostatic drugs with various mechanisms of action) induce cell-cycle arrest, apoptosis or necrosis depends on characteristic of the agent (concentration, time of exposure, mechanism of cytotoxic effect) and on biological status of target cells. Induction of apoptosis is the main principle of antitumour effect of low doses of ionising radiation or cytostatics. The decision whether the cellular response will be mobilisation of reparative proteins and stimulation of rescue mechanisms or induction of programmed cell death is a result of complicated pathways of cellular biochemistry. The damage of genetic material is evaluated in the cells and suitable response is then activated. Details of this deciding process remain unknown. Hypericin has been found to induce apoptosis in several tumours: glioma $(2,21)$, pituitary adenoma (6) retinal pigment epithelial cells (7), malignant T lymphocytes(5). Hypericin was shown to be potent inhibitor of protein kinase $\mathrm{C}$ (PKC) (15) and ability to induce apoptosis is contributed to the PKC inhibition (7). PKC is a family of intracellular enzymes that transduce extracellular signals to intracellular responses and specifically mediates signals leading to cell proliferation/growth regulation. However, efforts to define exact role of PKC in the induction of apoptosis are complicated by conflicting reports and remain to be elucidated. Unlike other potent PKC inhibitors (such as staurosporin) hypericin acts on regulatory domain of PKC and thus have higher specificity for inhibition of this enzyme. Inhibition of PKC by hypericin is strongly dependent on several factors, such as concentration, light and membrane integrity. Hypericin also acts as inhibitor of mitogen-activated protein (MAP) kinase and epidermal growth factor receptor tyrosine kinase (3) and inhibit mitochondrial hexokinase in HeLa cells in concentration and light dependent manner (14). 
Hypericin is well-known photosenzitizer. In the study of excited state of hypericin, the mean acidity of the hydroxyl groups of the molecule was shown to be markedly raised upon excitation into the singlet excited state. Since hypericin is relatively rigid polycyclic quinoid and thus the lightinduced change in dipole moment is expected to be small, the likely mode of excited state relaxation is proton dissociation as a result of lowering of the $\mathrm{pKa}$. The possibility of intramolecular proton transfers in hypericins could also be supported by their local structures (the proximity of hydroxyl groups to carbonyl groups), which are very close to that of 3-hydroxy flavone, a well-characterised prototype for intramolecular proton transfer. Although it is generally known that polarity, viscosity and hydrogen-bonding ability of solvents have marked effects on the proton transfer, only few solvent effects were observed for proton transfer of hypericin.

Although most of the photosensitization processes caused by hypericin appear to be mediated predominantly by ${ }^{1} \mathrm{O}_{2}$ (indicating type II mechanism) other oxygen radicals were also detected in some photosensitization reactions of hypericins. Model studies has demonstrated that the relative contribution of type I and type II in the photosensitizitation of hypericin depends on a number of factors, including photosensitizer concentration, substrate properties and concentration, light intensity and, as expected, concentration of oxygen in target tissue. Co-operations of type I and II reactions and their transformation in synchronisation with oxygen consumption is advantageous since rapid depletion of intracellular oxygen is common characteristic of illumination during photodynamic therapy (PDT) and the oxygen consumption can completely diminish type II response. Hypericin has been studied for PDT responses on several tumour cell lines. As in case of porphyrins, membrane structures like microsomes and mitochondria seem to be major targets for photosensitization. It has been found that hypericin is preferentially localised in the cytoplasm associated with the membrane fraction of subcelullar organelles. Interestingly, it appears that accumulation of hypericin in the nucleus is low.

In our previous studies $(11,12,19)$ we demonstrated apoptosis could be induced in human promyolcyte cell line HL-60 following $6 \mathrm{~h}$ incubation with $2 \%$ ethanol, $50 \mathrm{nmol} / 1$ idarubicin and irradiation by high doses of ionising radiation (20 Gy). In this study we investigated the ability of protein kinase $\mathrm{C}$ inhibitor hypericin to induce apoptosis in HL-60 cell line after photodynamic activation. We also compared antiproliferative and proapoptotic effect of photoactivated hypericin in promyelocyte leukemic cells HL-60 and pituitary adenoma cells AtT20/D16v-F2.

\section{Materials and Methods}

\section{Cell culture and culture conditions}

Human leukaemia HL-60 cells were obtained from the European Collection of Animal Cell Cultures (Porton Down,
Salisbury, UK) and were cultured in Iscove's medium (Sigma Inc.) supplemented with $20 \%$ fetal calf serum (FCS) in a humidified incubator at $37^{\circ} \mathrm{C}$ and controlled $5 \%$ $\mathrm{CO}_{2}$ atmosphere. The cultures were divided every $3^{\text {rd }}$ day by dilution to a concentration of $2 \times 10^{5}$ cells $/ \mathrm{ml}$.

Mouse pituitary AtT20/D16v-F2 cells were obtained from American Type Culture Collection (Manassas, VA, USA) and were cultured in Dulbecco's modified Eagle's medium (Sigma Inc.) supplemented with 10\% horse serum in a humidified incubator at $37^{\circ} \mathrm{C}$ and controlled $5 \% \mathrm{CO}_{2}$ atmosphere. The cells were harvested every $5^{\text {th }}$ day and diluted to a concentration of $1 \times 10^{5}$ cells $/ \mathrm{ml}$.

Cell count was performed with a haemocytometer, cell membrane integrity was determined using the Trypan blue exclusion technique. HL-60 and AtT20/D16v-F2 cells in the maximal range of 20 passages were used for this study.

\section{Cell treatments}

Exponentially growing HL-60 and AtT20/D16v-F2 cells were suspended at a concentration of $2 \times 10^{5}$ and $1 \times 10^{5}$ cells $/ \mathrm{ml}$ respectively in complete medium. $10 \mathrm{ml}$ of aliquots were plated into $25 \mathrm{~cm}^{2}$ flasks (Nunc) mixed with hypericin (Sigma Aldrich) at desired concentrations and photosensitised where required. $1 \mathrm{mg}$ of hypericin was dissolved in $1.5 \mathrm{ml}$ of solvent (ethanol $96 \%+$ glycerol $1: 1$ ) and diluted by $20 \%$ polyethylenglycol. At desired time the cells were harvested, counted and cell viability determined with the Trypan blue exclusion assay.

\section{Photosensitization of hypericin}

Because coherent laser light is not necessary for hypericin $(5,14)$, a simple wide emission spectrum light source was used. Cell culture flasks were exposed to white light from four fluorescent DULUX D G24d-2 $18 \mathrm{~W}$ bulbs $15 \mathrm{~cm}$ above the culture flasks. Photoactivation lasted for $18 \mathrm{minu}-$ tes and delivered the equivalent of $4.5 \mathrm{~J} / \mathrm{cm}^{2}$. The culture flasks were then incubated in dark at $37^{\circ} \mathrm{C}$ and controlled $5 \% \mathrm{CO}_{2}$ atmosphere.

\section{Cell morphology}

For calculation of the percentage of cells showing morphology of apoptosis, aliquots were removed from control and drug-treated cell cultures at various times of incubation and usually 400 cells were counted on Diff-Quik (Dade Behring) stained cytospin preparations. Apoptotic cells were identified by the condensed and fragmented state of their nuclei and focal protrusions of the cell surface.

\section{Cell surface markers and cell size analysis}

Flow cytometry was used for cell surface antigen analysis and for apoptosis monitoring. Cells were washed twice with PBS containing 5\% FCS. Then, $1 \times 10^{5}$ cells were suspended in $0.5 \mathrm{ml}$ PBS with $5 \%$ FCS and $0.02 \% \mathrm{NaN}_{3}$ and incubated with $\mathrm{mAb}$ APO2.7 for $30 \mathrm{~min}$ at $4^{\circ} \mathrm{C}$.

For apoptosis detection the mouse phycoerythrin (PE)conjugated mAb APO2.7 (clone 2.7 A6A3) (obtained from 
Immunotech) for detecting 7A6 antigen expressed by cells undergoing apoptosis has been used. We used method without cell permeabilisation.

Flow cytometric analysis was performed on a Coulter Epics XL flow cytometr. A minimum of 10000 cells was collected for each sample in a list mode file format. List mode data were analysed using Epics XL System II software colour eventing (Coulter Electronic, Hialeah, FL, USA).

\section{Cell cycle analysis}

Following 6 and 24 hours of incubation, the cells were washed with cold PBS, fixed by $70 \%$ ethanol and stained with propidium iodide (PI) in Vindelov's solution for $30 \mathrm{mi}-$ nutes at $37^{\circ} \mathrm{C}$. Fluorescence (DNA content) was measured with Coulter Electronic, Hialeah, FL, USA apparatus. A minimum of 10000 cells analysed in each sample served to determine the percentage of cells in each phase of cell cycle, using Multicycle AV software.

\section{Results}

Cell growth and viability

Fig. 1 shows the effects of hypericin on the proliferative rate of HL-60 cell line after 24h. Cultivation with 4-8 $\mu \mathrm{mol} / 1$ hypericin activated by light induced high inhibition of the rate of HL-60 cell growth. When hypericin treated cells were not exposed to light growth inhibition was insignificant. Fig. 2 shows the effects of hypericin on the proliferative rate of AtT20/D16v-F2 cells after 72 and $144 \mathrm{~h}$. Cultivation with $2-8 \mu \mathrm{mol} / 1$ hypericin did not significantly affected proliferative rate of AtT20/D16v-F2 cells. Cultivation with light activated hypericin in concentration $16 \mu \mathrm{mol} / 1$ slightly inhibited growth rate and the AtT20/D16v-F2 cells did not proliferate in presence of light activated $32 \mu \mathrm{mol} / 1$ hypericin.

\section{Morphologic changes}

HL-60 cells were incubated in the presence of $1 ; 2.5 ; 4$ and $8 \mu \mathrm{mol} / 1$ hypericin for 24 hours. After 6 and 24 hours cell morphology was examined. AtT20/D16v-F2 cells were incubated in the presence of $1 ; 2.5 ; 4 ; 8 ; 16$ and 32 $\mu \mathrm{mol} / 1$ hypericin for 6 days. After 72 and 144 hours cell morphology was examined. Cell morphology was examined on Diff-Quik stained cytospin preparations. Morphologic evidence of apoptosis was found in HL-60 cells treated with 1-8 $\mu \mathrm{mol} / 1$ light activated hypericin. The increase in the proportion of apoptotic cells was dose and light dependent (fig. 3), with maximum of apoptotic cells detected after 8 $\mu \mathrm{mol} / 1$ light activated hypericin (36.9\% of live cells).

\section{Analysis of cell-cycle and sub-diploid DNA content}

We assessed DNA cleavage in the aforementioned hypericin-treated tumour cells. We have observed that light activated hypericin induces both apoptosis and necrosis in dose and time dependent manners in HL-60 cells (tab.1, fig. 4), but causes only necrosis in AtT20/D16v-F2 cells (fig. 5).

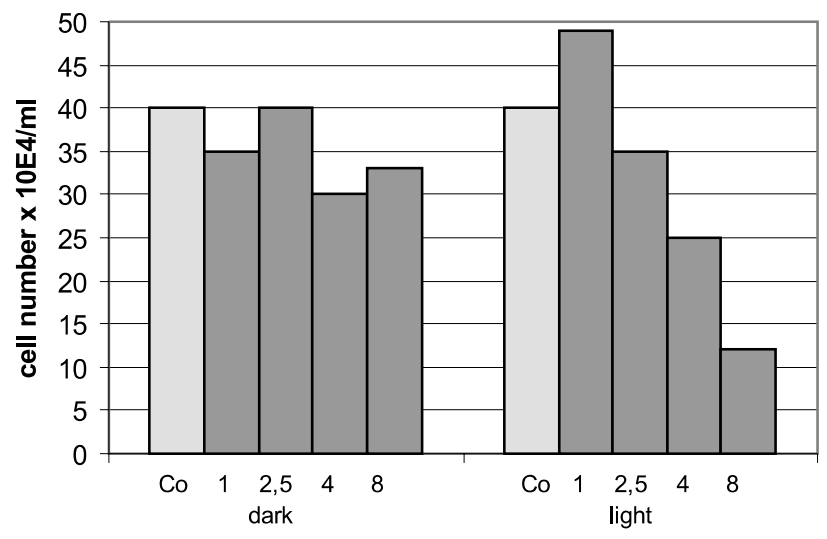

Fig. 1: Effect of hypericin on the proliferative rate of HL-60 cell line after 24 hours of incubation. HL-60 cells were exposed to various hypericin concentrations (1-8 $\mu \mathrm{mol} / 1)$. Number of viable cells was determined by Trypan blue staining.

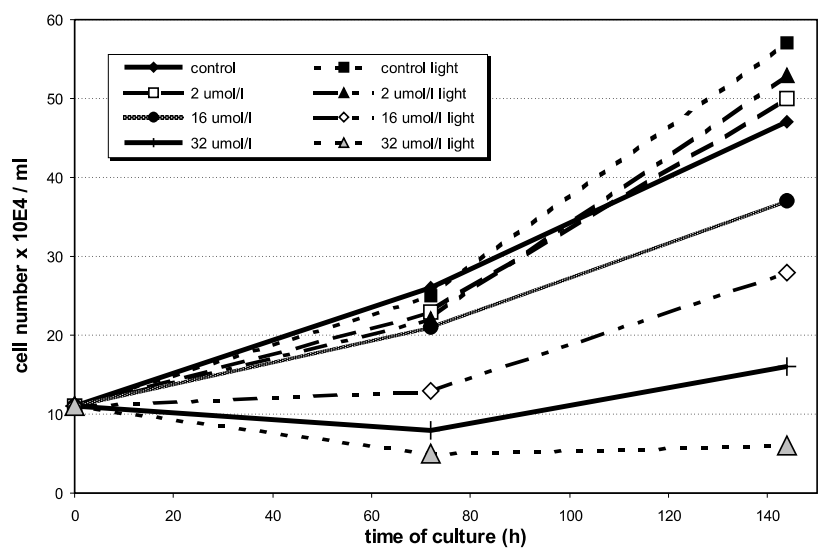

Fig. 2: Kinetic of hypericin effect on the proliferative rate of AtT20/D16v-F2 cells. AtT20/D16v-F2 cells were exposed to various hypericin concentrations $(2-32 \mu \mathrm{mol} / 1)$.

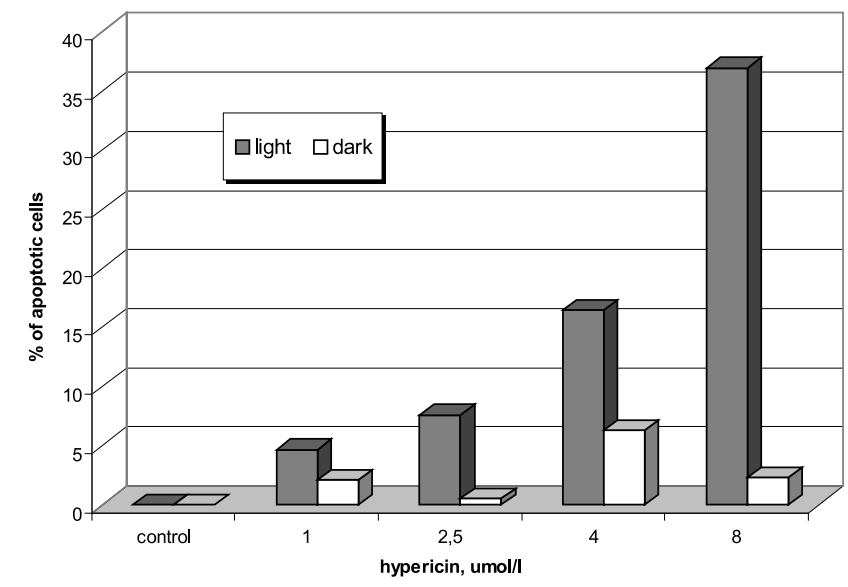

Fig. 3: Dose dependence of apoptosis in HL-60 cells exposed to hypericin as determined by cell morphology examined on Diff-Quik stained cytospin preparations after $24 \mathrm{~h}$ incubation. Data represent medium values from 3 independent experiments. 
Tab. 1:

\begin{tabular}{|c|c|c|c|c|c|c|c|c|}
\hline & & hypericin $\mu \mathrm{mol} / 1$ & $\%$ apoptotic cells & $\%$ necrotic cells & & hypericin $\mu \mathrm{mol} / \mathrm{l}$ & $1 \%$ apoptotic cells & $\%$ necrotic cells \\
\hline \multirow[t]{4}{*}{$6 \mathrm{~h}$} & \multirow[t]{4}{*}{ light } & control & 2,7 & 18,5 & \multirow[t]{4}{*}{ dark } & control & 0,8 & 13,1 \\
\hline & & 2,5 & 7,0 & 28,8 & & 2,5 & 4,2 & 23,7 \\
\hline & & 4 & 10,2 & 33,4 & & 4 & 9,2 & 31,0 \\
\hline & & 8 & 22,9 & 48,3 & & 8 & 8,7 & 29,1 \\
\hline \multirow[t]{4}{*}{$24 \mathrm{~h}$} & \multirow[t]{4}{*}{ light } & control & 5,2 & 20,6 & \multirow[t]{4}{*}{ dark } & control & 0,0 & 3,5 \\
\hline & & 2,5 & 14,4 & 31,3 & & 2,5 & 2,9 & 13,5 \\
\hline & & 4 & 30,3 & 31,2 & & 4 & 10,0 & 18,1 \\
\hline & & 8 & 48,7 & 50,5 & & 8 & 9,7 & 26,9 \\
\hline
\end{tabular}

$6 \mathrm{~h}$ dark
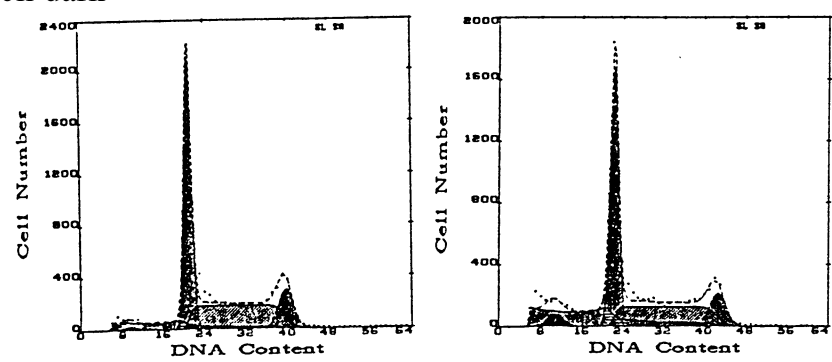

6h light

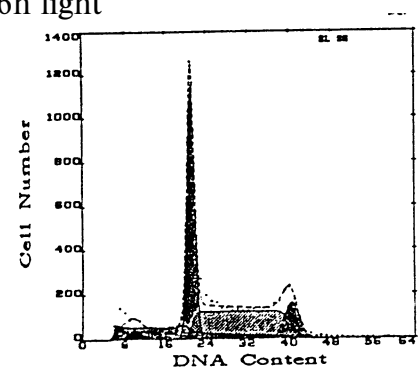

24h dark

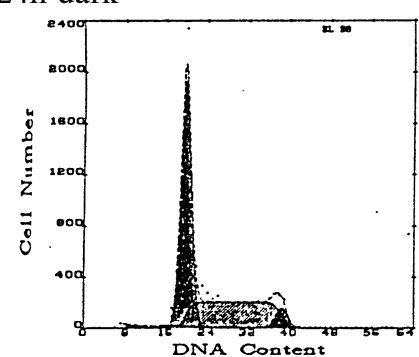

$24 \mathrm{~h}$ light

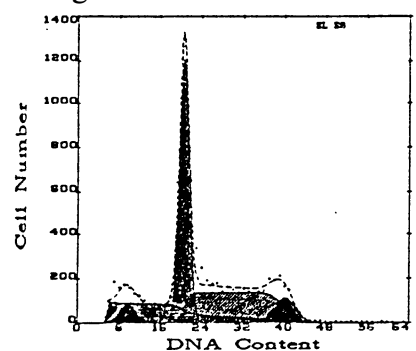

Control

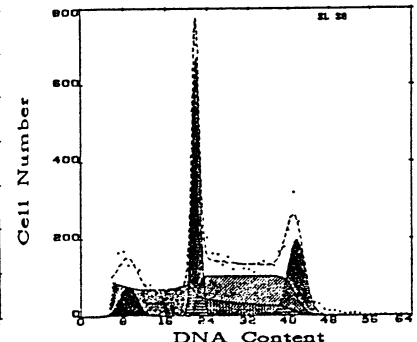

DNA Content
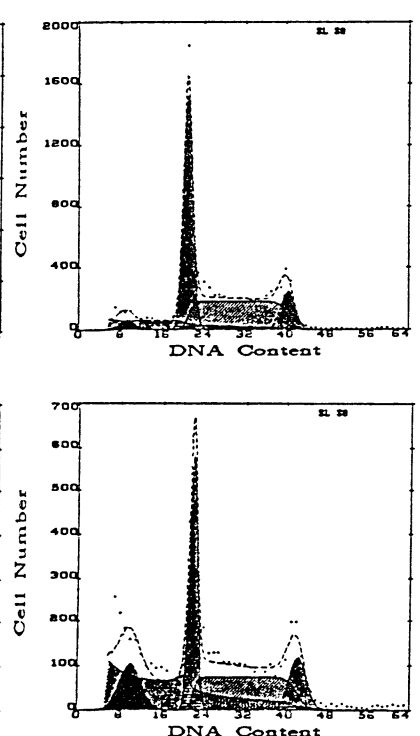

$2,5 \mu \mathrm{mol} / 1$
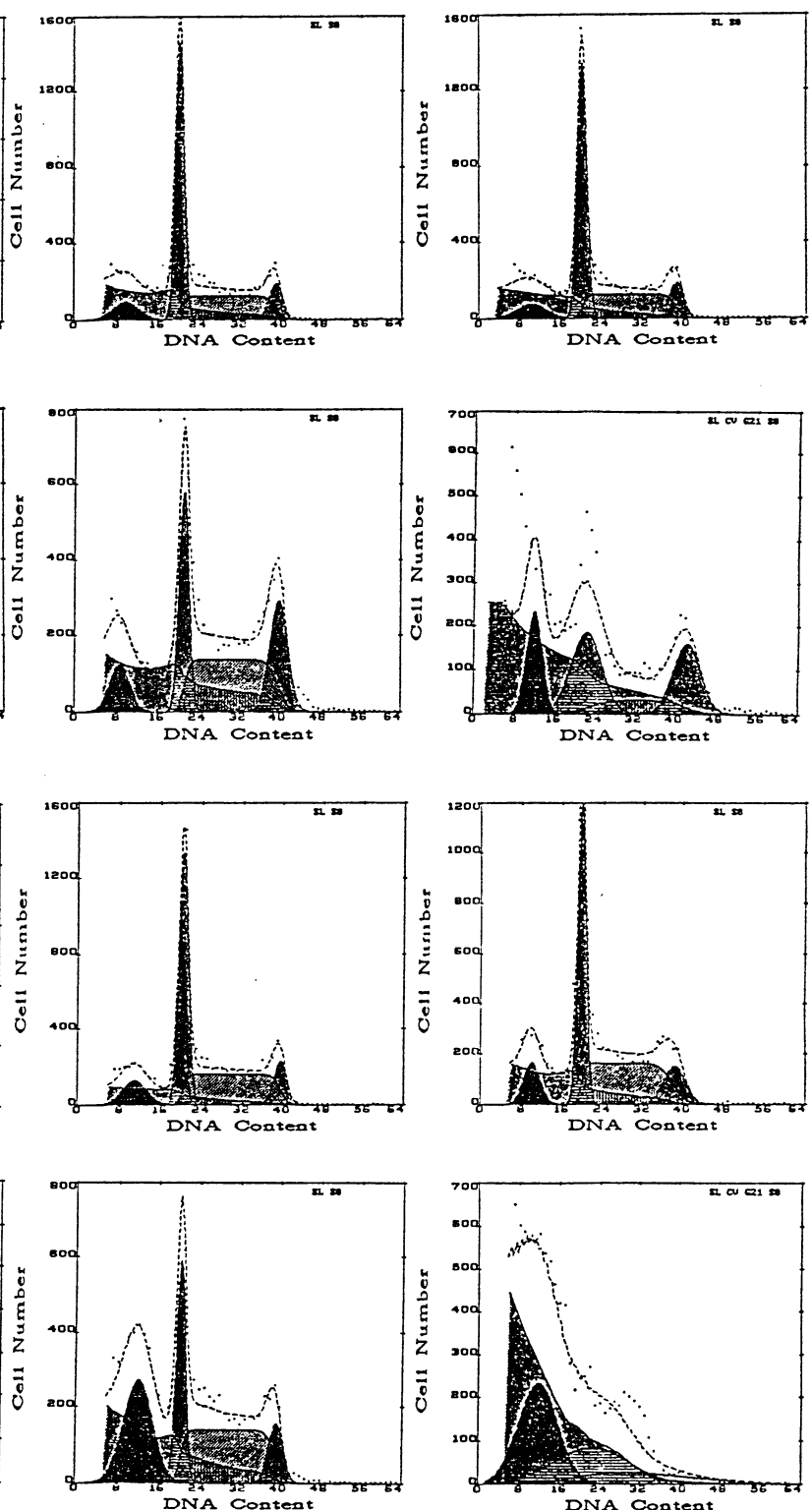

$4 \mu \mathrm{mol} / 1$

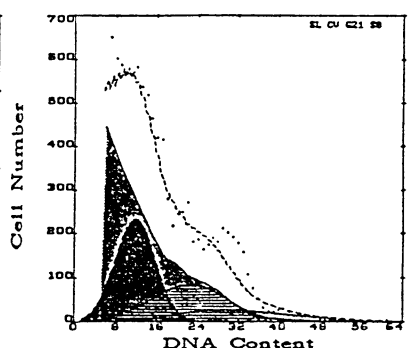

$8 \mu \mathrm{mol} / 1$

Fig. 4: Flow cytometric analysis of DNA content and cell-cycle after treatment of HL-60 cells with 2.5-8 $\mu$ mol/1 hypericin. Apoptotic cells are identified as cells with subdiploid DNA content (lower DNA content than cells in $\mathrm{G}_{0} / \mathrm{G}_{1}$ phase), i.e. subG $_{1}$ peak. Representative results for single experiment are shown. 


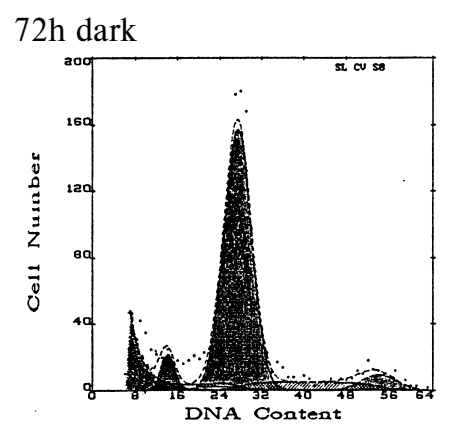

$72 \mathrm{~h}$ light

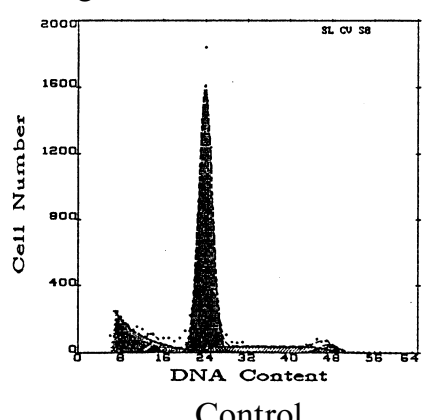

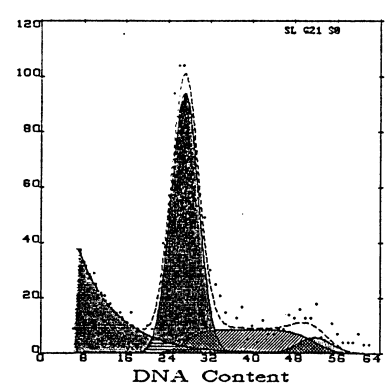

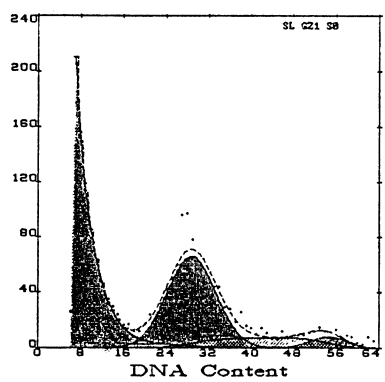

$32 \mu \mathrm{mol} / 1$

Fig. 5: Flow cytometric analysis of DNA content and cell-cycle after treatment of AtT20/D16v-F2 cells with $32 \mu \mathrm{mol} / 1$ hypericin. Apoptotic cells are identified as cells with subdiploid DNA content (lower DNA content than cells in $G_{0} / G_{1}$ phase), i.e. subG $_{1}$ peak. Representative results for single experiment are shown.

Dark
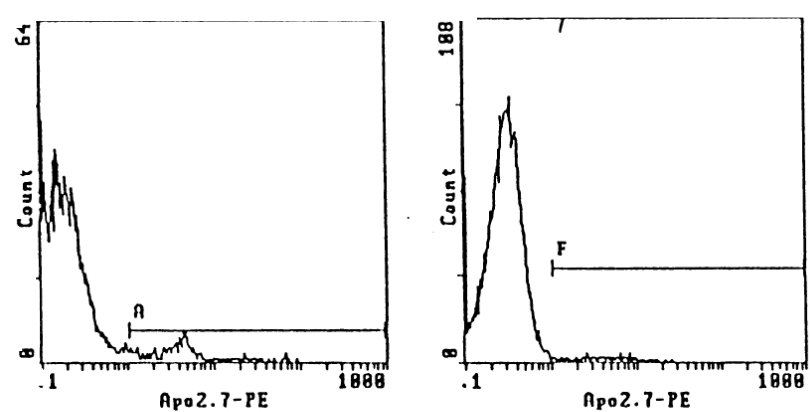

Light
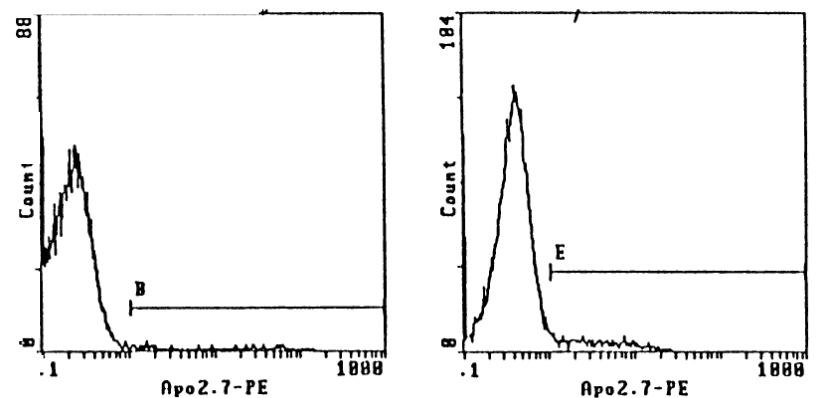
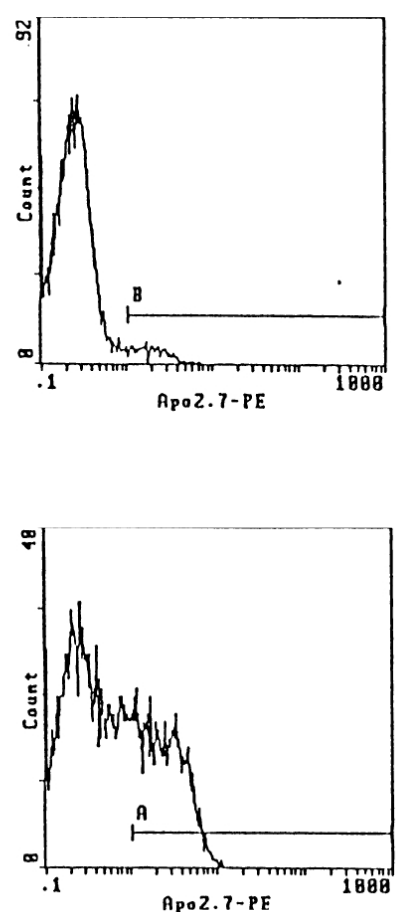

Fig. 6: Histograms for cell number versus APO2.7-PE fluorescence intensity of unprocessed HL-60 cells after treatment with 2.5-8 $\mu \mathrm{mol} / 1$ hypericin. Representative results for single experiment are shown. 
Flow cytometric detection of apoptotic cells using monoclonal antibody APO2.7

Since 7A6 antigen is selectively expressed on the mitochondrial membrane in cells undergoing apoptosis, we attempted to detect apoptotic cells using APO2.7 monoclonal antibody after $2.5 ; 4$ and $8 \mu \mathrm{mol} / 1$ hypericin treatment of HL-60 cells for 24 hours. Fraction of cells stained by APO2.7 antibody significantly increased from $4.4 \%$ (control) to $35.9 \%$ ( $8 \mu \mathrm{mol} / 1$ light activated hypericin) at $24 \mathrm{~h}$ after treatment while no increase of apoptotic cells was detected on cells treated with lower hypericin concentrations or in complete darkness (fig. 6).

\section{Discussion and Conclusions}

Cell death no longer can be considered solely in terms of the catastrophic failure of homeostasis that typifies necrosis. Cells and multicellular organisms share the ability to activate an internal death program known as apoptosis. One of generally accepted axioms about apoptosis is that it is easier to induce apoptosis in cell populations undergoing rapid turnover at physiological conditions. Therefore it is difficult to inhibit cellular growth and induce apoptosis in pituitary adenoma cells. AtT20/D16v-F2 pituitary cells are resistant to ionising radiation and idarubicin treatment, inhibition of cellular growth is apparent only after high doses, although these stimuli are good apoptosis inductors in leukemic HL-60 cells $(11,19)$. In this study we evaluated effect of hypericin, potent specific PKC inhibitor.

The PKC signal transduction system has been shown to be involved in the regulation of cellular growth, differentiation and gene transcription. In pituitary cells, this enzyme is also believed to modulate hormone synthesis and secretion. Differing from more classic PKC inhibitors, such as staurosporin or tamoxifen, which competitively block the ATP catalytic site, hypericin inhibits PKC by interacting with regulatory domain of the enzyme and displays more selectivity in its inhibitory effect. Direct interaction of hypericin with PKC might be one of its potential cytotoxic mechanisms. It is also possible that photoactivated hypericin may be acting indirectly, through the generation of singlet oxygen, to inhibit proliferation and induce apoptosis.

We show in this study, that hypericin causes both, apoptosis and necrosis, in leukaemic HL-60 cells, but only causes necrosis in pituitary AtT20/D16v-F2 cells. Effect on both types of cell lines is strongly dependent on photoactivation of hypericin.

Hypericin induced apoptosis has been reported in studies dealing with its inhibitory effect on PKC $(6,7,21)$. Unfortunately, in these studies little attention was paid to light and photosensitization conditions, although it has been shown previously, that PKC inhibition by hypericin is strongly dependent on light dose (17).

Molecular mechanisms underlying hypericin mediated cell photokilling are yet unclear. Numerous studies have demonstrated the important role of mitochondria in apopto- sis initiation and recently an effect of photoactivated hypericin on mitochondrial structure and function has been studied. Light activated hypericin induces spectrum of degenerative changes in mitochondia, including loss of matrix density, mitochondrial swelling and disorganised cristae (14). Photoactivated hypericin triggers release of mitochondrial cytochrome $\mathrm{c}$ into cytosol of HeLa cells and induces apoptosis of HeLa cells independently from the pathway mediated by caspase- 1 and caspase- 8 , while caspase-3 was found to be a key mediator of hypericin induced apoptosis in HeLa cells (18). APO2.7 (anti-7A6) is monoclonal antibody which reacts preferentially with a $38-\mathrm{kDa}$ mitochondrial membrane protein in cells undergoing apoptosis. The antigen identified by APO2.7 appears relatively early in the apoptotic process and thus, when the cell has become permeable as a result of events in late apoptosis/necrosis it is no longer necessary for the investigator to use a permeabilisation agent, since the antigen is available for staining (12). In our study photoactivated hypericin induced significant apoptosis human promyelocyte leukemia cells HL-60 despite the fact that these cells of do not have TP53 gene, but only induced necrosis and inhibited proliferation in slowly proliferating pituitary AtT20/D16v-F2 cells. Surprisingly, hypericin did not significantly affect progression of cells through cell cycle, suggesting that the cells die by rapid interphase apoptosis, where the apoptosis is triggered in all phases of cell cycle.

This work was supported by grants from Grant Agency of Charles University (GA UK 279/98), from Grant Agency of Ministry of Health (IGA-MZ: NB/6172-3) and in part by research project J13/98: 111500001.

\section{References}

1. Carpenter S and Kraus GA. Photosensitization is required for inactivation of equine infectious anemia virus by hypericin. Photochem Photobiol 1991;53(2): $169-74$.

2. Couldwell WT, Gopalakrishna R, Hinton DR et al. Hypericin: a potential antiglioma therapy (published erratum appears in Neurosurgery 1994 Nov;35(5):993). Neurosurgery 1994;35(4):705-10.

3. De Witte $\mathrm{P}$, Agostinis $\mathrm{P}$, Van Lint $\mathrm{J}$ et al. Inhibition of epidermal growth factor receptor tyrosine kinase activity by hypericin. Biochem Pharmacol 1993;46(11):1929-36.

4. Durán N and Song PS. Hypericin and its photodynamic action. Photochem Photobiol 1986;43(6):677-80.

5. Fox FE, Niu Z, Tobia A et al. Photoactivated hypericin is an anti-proliferative agent that induces a high rate of apoptotic death of normal, transformed, and malignant $\mathrm{T}$ lymphocytes: implications for the treatment of cutaneous lymphoproliferative and inflammatory disorders. J Invest Dermatol 1998;111(2):327-32.

6. Hamilton HB, Hinton DR, Law RE et al. Inhibition of cellular growth and induction of apoptosis in pituitary adenoma cell lines by the protein kinase $\mathrm{C}$ inhibitor hypericin: potential therapeutic application. J Neurosurg 1996;85(2): 329-34.

7. Harris MS, Sakamoto $\mathrm{T}$, Kimura $\mathrm{H}$ et al. Hypericin inhibits cell growth and induces apoptosis in retinal pigment epithelial cells: possible involvement of protein kinase C. Curr Eye Res 1996;15(3):255-62.

8. Hudson JB, Graham EA and Towers GH. Antiviral assays on phytochemicals: the influence of reaction parameters. Planta Med 1994;60(4):329-32.

9. Hudson JB, Lopez-Bazzocchi I and Towers GH. Antiviral activities of hypericin. Antiviral Res 1991;15(2):101-12.

10. Lavie G, Valentine F, Levin B et al. Studies of the mechanisms of action of the antiretroviral agents hypericin and pseudohypericin. Proc Natl Acad Sci USA 1989;86(15):5963-7. 
11. Mareková M, Vávrová J, Vokurková D. Dose Dependent Biological Effects of Idarubicin in HL-60 Cells: Alterations of the Cell-cycle and Apoptosis. Act Medica 2000;43(2):69-73.

12. Mareková M, Vávrová J, Vokurková D. Ethanol Induced Apoptosis in Human HI60 Cells. Gen Physiol Biophys 2000; in press

13. Meruelo D, Lavie G and Lavie D. Therapeutic agents with dramatic antiretroviral activity and little toxicity at effective doses: aromatic polycyclic diones hypericin and pseudohypericin. Proc Natl Acad Sci U S A 1988;85(14):5230-4.

14. Miccoli L, Beurdeley-Thomas A, De Pinieux G et al. Light-induced photoactivatiopn of hypericin affects the energy metabolism of human glioma cells by inhibiting hexokinase bound to mitochondria. Cancer Res 1998;58:5777-86.

15. Takahashi I, Nakanishi S, Kobayashi E et al. Hypericin and pseudohypericin specifically inhibit protein kinase $\mathrm{C}$ : possible relation to their antiretroviral activity. Biochem Biophys Res Commun 1989;165(3):1207-12.

16. Tang J, Colacino JM, Larsen SH et al. Virucidal activity of hypericin against enveloped and non-enveloped DNA and RNA viruses. Antiviral Res 1990;13(6):313-25

17. Utsumi T, Okuma M, Utsumi T et al. Light-Dependent Inhibition of Protein Kinase $\mathrm{C}$ and superoxide Generation of Neutrophils by Hypericin, an Antiretroviral Agent. Arch Biochem Biophys 1995;316(1):493-7.

18. Vantieghem A, Assefa Z, Vandenabeele P et al. Hypericin-induced photosensitization of HeLa cells leads to apoptosis or necrosis. FEBS Lett 1998;440:19-24.
19. Vávrová J, Mareková M, Vokurková D. Lidské hematologické nádorové linie a jejich citlivost $\mathrm{k}$ účinkům ionizujícího záŕení. Voj Zdrav Listy 2000; in press.

20. Yang X, Goncalves J and Gabuzda D. Phosphorylation of Vif and its role in HIV 1 replication. J Biol Chem 1996;271(17):10121-9.

21. Zhang W, Hinton DR, Surnock AA et al. Malignant glioma sensitivity to radiotherapy, high-dose tamoxifen, and hypericin: corroborating clinical response in vitro: case report. Neurosurgery 1996;38(3):587-1.

Submitted September 2000.

Accepted January 2001.

MUDr. Martina Mareková,

Charles University in Prague,

Faculty of Medicine in Hradec Králové,

Department of Medical Biochemistry,

Šimkova 870, 50001 Hradec Králové,

Czech Republic.

e-mail: marekova@lfhk.cuni.cz 